\title{
IMPLIKASI SISTEM PENGISIAN KEANGGOTAAN DEWAN PERWAKILAN DAERAH REPUBLIK INDONESIA TERHADAP NILAI-NILAI PANCASILA
}

\author{
Ratna Herawati \\ Fakultas Hukum Universitas Diponegoro \\ Jl Prof Soedarto, S. H. , Tembalang Semarang, \\ email :ratna_h27@yahoo.com
}

\begin{abstract}
The problems in this study: 1) How ismembership system of the House of Regional Representative based on Law No. 8 In 2012? 2) What is implicationmembership system the House of Regional Representative to the values of Pancasila? Review of the implications of membership system of the the House of Regional Representative against the values of Pancasila implemented with normative juridical approach. As for the interview just as crosscheck the data, obtained from secondary data. The conclusion from these results that the membership system of the House of Regional Representative based on Law No. 8 In 2012 the system uses a lot of proxy district. As for the implications of membership system of the House of Regional Representative against the values of Pancasila: Pancasila related to the rule of law as Indonesia, Pancasila as a source of substantive law, and the translation of the values of Pancasila in Principles of Law.
\end{abstract}

Keywords : Membership System of the House of Regional Representative, Pancasila .

\begin{abstract}
Abstrak
Permasalahan dalam penelitian ini: 1) Bagaimanakah sistem pengisian keanggotaan Dewan Perwakilan Daerah berdasarkan UU No. 8 Tahun 2012? 2) Apasajakah implikasi sistem pengisian keanggotaan Dewan Perwakilan Daerah terhadap nilai-nilai Pancasila? Peninjauan terhadap implikasi sistem pengisian keanggotaan Dewan Perwakilan Daerah terhadap nilai-nilai Pancasila dilaksanakan dengan pendekatan yuridis normatif. Adapun wawancara hanya sebagai crosscheck data, yang didapatkan dari data sekunder. Kesimpulan dari hasil penelitian ini bahwa sistem pengisian keanggotaan Dewan Perwakilan Daerah berdasarkan UU No. 8 Tahun 2012 memakai sistem distrik berwakil banyak. Adapun implikasi sistem pengisian keanggotaan Dewan Perwakilan Daerah terhadap nilai-nilai Pancasila berkaitan dengan Pancasila sebagai tertib hukum Indonesia, Pancasila sebagai sumber hukum materiil, dan penjabaran nilai-nilai Pancasila dalam Asas-Asas Hukum.
\end{abstract}

Kata kunci : Sistem Pengisian Keanggotaan Dewan Perwakilan Daerah, Pancasila.

\section{A. Pendahuluan}

1. Latar Belakang

Salah satu aspek penting yang terkandung dalam UUD Negara RI Tahun 1945 mengenai falsafah bangsa, yaitu Pancasila. Dengan Pancasila sebagai falsafah hidup, bangsa Indonesia mewujudkan citacita nasionalnya, sebagaimana tercantum dalam Pembukaan UUD Negara RI Tahun 1945.

Adapun dasar hukum Indonesia sebagai negara demokrasi tercantum pada UUD Negara Republik Indonesia 1945 Pasal 1 Ayat
( 2 ) yang menyebutkan bahwa "Kedaulatan berada di tangan rakyat dan dilaksanakan menurut Undang-Undang Dasar". Maka pasal tersebut dapat dikatakan benar-benar menjamin, mengoptimalkan serta meneguhkan paham kedaulatan rakyat yang dianut negara Indonesia. Dari Pasal 1 Ayat (2) tersebut menunjukkan bahwa Indonesia merupakan sebuah negara yang menjunjung tinggi demokrasi.

Gagasan demokrasi tersebut berdasarkan prinsip-prinsip Pancasila sebagai suatu keputusan politik, dikatakan benar jika 
memenuhi setidaknya 4 (empat) syarat.

Syarat-syarat tersebut: pertama, harus didasarkan pada asas rasionalitas dan keadilan sehingga bukan hanya berdasarkan subjektivitas ideologis dan kepentingan; kedua, didedikasikan bagi kepentingan banyak orang dan bukan demi kepentingan perseorangan atau golongan; ketiga, berorientasi jauh sehingga bukan demi kepentingan jangka pendek, melalui akomodasi transaksional yang bersifat toleransi negatif; dan keempat, bersifat imparsial dengan melibatkan dan mempertimbangkan pendapat semua pihak. ${ }^{1}$

Pelaksanaan dari demokrasi di Indonesia dengan mengakui Majelis Permusyawaratan Rakyat (selanjutnya disingkat MPR) sebagai penjelmaan dari kedaulatan rakyat. MPR terdiri atas anggota Dewan Perwakilan Rakyat (selanjutnya disebut DPR) dan anggota Dewan Perwakilan Daerah (selanjutnya disebut DPD). Sebelum perubahan UUD 1945, MPR terdiri dari anggota DPR ditambah dengan utusan-utusan dari daerah-daerah (selanjutnya disebut Utusan Daerah) dan golongan-golongan, menurut aturan yang ditetapkan dengan undang-undang. Keanggotaan melalui Utusan Daerah dan golongan-golongan tersebut tidak melalui Pemilihan Umum (selanjutnya disingkat Pemilu), sehingga Utusan Daerah dan golongan-golongan tersebut dianggap tidak efektif. Dengan demikian dalam rangka mengakomodasi kepentingan dari daerah secara efektif, maka dibentuklah DPD, yang keanggotaannya dipilih melalui Pemilu.

Adapun pembentukan DPD meliputi pertimbangan teoritis dan politis.

Dasar pertimbangan teoritis mengenai keberadaan DPD: untuk membangun sebuah mekanisme kontrol dan keseimbangan (checks and balances) antar cabang kekuasaan negara dan dalam lembaga legislatif itu sendiri. Selain itu DPD diharapkan mampu menjamin dan menampung kepentingan daerah-daaerah secara memadai serta memperjuangkan aspirasi dan kepentingan daerah dalam lembaga legislatif. Bukan berarti dengan cara seperti itu kepentingan nasional akan dikurangi karena bagaimanapun DPD adalah lembaga negara yang bersifat nasional sebagaimana DPR. Hanya saja mekanisme pemilihan dan persyaratan pencalonan anggotanya lebih banyak dikaitkan dengan daerah, bukan penduduk. Kehadiran DPD juga mempunyai dasar pertimbangan politis: memperkuat ikatan daerah-daerah dalam wadah Negara Kesatuan Republik Indonesia dan meningkatkan aspirasi dan kepentingan daerah-daerah dalam perumusan kebijakan nasional. $^{2}$

Pengisian keanggotaan DPD sebagai lembaga perwakilan yang dipilih melalui Pemilu, mempunyai legitimasi yang tinggi. Dengan demikian DPD mempunyai kewenangan yang besar sesuai dengan fungsinya sebagai lembaga perwakilan. Akan tetapi, untuk menjaga koherensi internal, di mana kekuasaan membuat undang-undang telah diberikan kepada DPR maka DPD tidak diberikan kekuasaan yang sama dengan DPR sebagai pembuat undang-undang.

Hal-hal tersebut mendorong peneliti untuk mengkaji mengenai "Implikasi Sistem Pengisian Keanggotaan Dewan Perwakilan Daerah Republik Indonesia Terhadap NilaiNilai Pancasila”.

Berdasarkan latar belakang tersebut, perumusan masalah dalam penelitian ini:

1. Bagaimanakah sistem pengisian keanggotaan Dewan Perwakilan Daerah Republik Indonesia berdasarkan UndangUndang Nomor 8 Tahun 2012?

2. Apasajakah implikasi sistem pengisian keanggotaan Dewan Perwakilan Daerah Republik Indonesia terhadap nilai-nilai Pancasila?

\section{Metode Penelitian}

Pendekatan dalam penelitian ini adalah

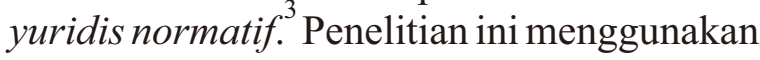
data sekunder, yang mencakup Bahan Hukum

\footnotetext{
1. Yudi Latif, 2011, Negara Paripurna: Historitas, Rasionalitas, dan Aktualitas Pancasila, Jakarta, PT Gramedia, hlm. 478.

2.Kelompok DPD di MPR RI, 2007, Untuk Apa DPD RI, Jakarta, Kelompok DPD di MPR RI, hlm. 37.

3.Soerjono Soekanto dan Sri Mamudji, 2001, Penelitian Hukum Normatif Suatu Tinjauan Singkat, Jakarta, PT Raja Grafindo Persada, hlm. 13-14.
} 
Primer, Bahan Hukum Sekunder, dan Bahan Hukum Tersier. Adapun keterangan atau penjelasan dari para ahli/pejabat/masyarakat dalam rangka untuk menjelaskan yang terdapat dalam data sekunder (crosscheck). Spesifikasi dalam penelitian ini adalah deskriptif analitis. Teknik untuk menganalisis data dalam penelitian ini adalah metode analisis kualitatif yaitu pengkajian data berupa tulisan bukan data berupa angka.

\section{Kerangka Teori \\ 1. Tinjauan Umum Nilai dan Norma}

Pancasila adalah sebagai ideologi, yaitu sebagai suatu sistem pemikiran (system of thought) yang bersifat terbuka. Artinya bahwa Pancasila sebagai cita-cita yang sudah hidup dalam masyarakat, ditemukan dan digali dari masyarakat itu sendiri. Oleh karena itu nilainilai yang terkandung dalam Pancasila sebagai ${ }_{4}$ ideologi terbuka adalah sebagai berikut:

a. Nilai Dasar, yaitu hakikat kelima sila Pancasila yaitu Ketuhanan, kemanusiaan, persatuan, kerakyatan dan keadilan. Nilai dasar tersebut adalah merupakan esensi dari sila-sila Pancasila yang bersifat universal, sehingga dalam nilai dasar tersebut terkandung cita-cita, tujuan serta nilainilai yang baik dan benar. Nilai dasar ideologi tersebut tertuang dalam Pembukaan Undang-Undang Dasar 1945 merupakan suatu norma dasar yang merupakan tertib hukum tertinggi, sebagai sumber hukum positif sehingga dalam negara memiliki kedudukan sebagai 'staatsfundamentalnorm' atau pokok kaidah negara yang fundamental. Sebagai ideologi terbuka nilai dasar inilah yang bersifat tetap dan terlekat pada kelangsungan hidup negara, sehingga mengubah Pembukaan Undang-Undang Dasar 1945 yang memuat nilai dasar ideologi Pancasila tersebut sama halnya dengan pembubaran negara. Adapun nilai dasar tersebut kemudian dijabarkan dalam pasal-pasal Undang-Undang Dasar 1945 yang didalamnya terkandung lembaga-lembaga penyelenggaraan negara, hubungan antara lembaga penyelenggara negara beserta tugas dan wewenangnnya.

b. Nilai Instrumental, yang merupakan arahan, kebijakan, strategi, sasaran serta lembaga pelaksanaannya. Nilai instrumental ini merupakan eksplisitasi, penjabaran lebih lanjut dari nilai-nilai dasar ideologi Pancasila. Pada aspek ini senantiasa dapat dilakukan perubahan (reformatif).

c. Nilai Praksis, yaitu merupakan realisasi nilai-nilai instrumental dalam suatu realisasi pengamalan yang bersifat nyata, dalam kehidupan sehari-hari dalam bermasyarakat, berbangsa dan bernegara. Dalam reaksi praksis inilah maka penjabaran nilai-nilai Pancasila senantiasa berkembang dan selalu dapat dilakukan perubahan dan perbaikan (reformasi) sesuai dengan perkembangan zaman ilmu pengetahuan dan teknologi serta aspirasi masyarakat.

Nilai dianggap abstrak, sehingga perlu dirumuskan ke dalam sesuatu yang lebih konkrit. Oleh karena itu nilai diwujudkan dalam bentuk norma.

Norma menurut Purnadi Purbacaraka dan Soerjono Soekanto dibedakan menjadi norma pribadi (otonom) dan antar-pribadi (heteronom). Norma pribadi dibedakan menjadi norma keagamaan dan norma kesusilaan. Sedangkan norma antar-pribadi terdiri dari norma sopan-santun dan norma hukum.

\section{Tinjauan Umum Pancasila}

Pancasila terdiri atas sila-sila Pancasila.

\footnotetext{
4. Kaelan, 2010, Pendidikan Pancasila, Yogyakarta, Paradigma,hlm. 120.

5. Shidarta, "Menilik Kepantasan Labelisasi Pancasila sebagai Staatsfundamentalnorm dalam Sistem Hukum Indonesia", sebuah Makalah yang dipresentasikan pada Seminar Nasional "Membangkitkan Semangat Konstitusi Berdasarkan Nilai-Nilai Pancasila dalam Negara Hukum Indonesia" oleh BEM Fakultas Hukum UNDIP, (Semarang, 1 Desember 2012), hlm. 2.
} 
Setiap sila pada hakikatnya merupakan suatu asas sendiri sehingga memiliki fungsi sendirisendiri, namun secara keseluruhan merupakan suatu kesatuan yang sistematis. Sila-sila Pancasila merupakan suatu kesatuan dan keutuhan yaitu setiap sila merupakan bagian yang mutlak dari Pancasila. Dengan demikian setiap sila tidak dapat berdiri sendiri terlepas dari sila-sila lainnya serta di antara sila yang satu dengan sila lainnya tidak saling bertentangan. Kesatuan sila-sila Pancasila memiliki sifat saling mengisi dan saling mengkualifikasi. Hal ini berarti bahwa dalam setiap sila terkandung nilai keempat sila lainnya. Hal ini dikarenakan nilai-nilai Pancasila sebagai suatu sistem, yaitu suatu kesatuan bagian-bagian yang saling berhubungan, saling bekerjasama untuk suatu tujuan tertentu dan secara keseluruhan merupakan suatu kesatuan yang utuh. ${ }^{6}$

Kesatuan sila-sila Pancasila menggambarkan hubungan hierarkhi baik dalam hal kuantitas maupun dalam hal isi sifatnya yang berkaitan dengan makna serta hakikat sila-sila Pancasila. Adapun rumusan Pancasila yang menggambarkan hubungan hierarkhi yaitu Sila pertama (Ketuhanan yang Maha Esa) meliputi dan menjiwai sila Kemanusiaan yang Adil dan Beradab, Persatuan Indonesia, Kerakyatan yang dipimpin oleh Hikmat Kebijaksanaan dalam Permusyawaratan/Perwakilan, serta Keadilan Sosial bagi Seluruh Rakyat Indonesia; Sila kedua (Kemanusiaan yang Adil dan Beradab) diliputi dan dijiwai oleh sila Ketuhanan yang Maha Esa, meliputi dan menjiwai sila Persatuan Indonesia, Kerakyatan yang dipimpin oleh Hikmat Kebijaksanaan dalam Permusyawaratan/Perwakilan, serta Keadilan Sosial bagi Seluruh Rakyat Indonesia; Sila ketiga (Persatuan Indonesia) diliputi dan dijiwai sila Ketuhanan yang Maha Esa, Kemanusiaan yang Adil dan Beradab, meliputi dan menjiwai sila Kerakyatan yang dipimpin oleh Hikmat Kebijaksanaan dalam
Permusyawaratan/Perwakilan, serta Keadilan Sosial bagi Seluruh Rakyat Indonesia; Sila keempat (Kerakyatan yang dipimpin oleh $\mathrm{Hikmat} \mathrm{kebijaksanaan} \mathrm{dalam}$ Permusyawaratan/Perwakilan), diliputi dan dijiwai oleh sila Ketuhanan yang Maha Esa, Kemanusiaan yang Adil dan Beradab, Persatuan Indonesia, serta meliputi dan menjiwai sila Keadilan Sosial bagi Seluruh Rakyat Indonesia; dan Sila kelima (Keadilan Sosial bagi Seluruh Rakyat Indonesia) diliputi dan dijiwai oleh Sila Ketuhanan yang Maha Esa, Kemanusiaan yang Adil dan Beradab, Persatuan Indonesia, serta Kerakyatan yang dipimpin oleh Hikmat Kebijaksanaan dalam Permusyawaratan/Perwakilan.

\section{Tinjauan Umum Demokrasi berdasarkan Pancasila}

Demokrasi terwujud dengan terbentuknya pemerintahan oleh rakyat dan berorientasi kepada kepentingan rakyat. Prinsip Kedaulatan rakyat ini, sering disebut demokrasi, hendak mengatakan bahwa rakyat sendiri yang berwenang untuk menentukan dipimpin dan oleh siapa. ${ }^{7}$ Meskipun demikian, rakyat tidak dapat memerintah atau mengartikulasikan kepentingannya secara sendiri-sendiri. ${ }^{8}$ Tindakan-tindakan pemerintah tidak diselenggarakan secara langsung oleh warga negara tetapi secara tidak langsung melalui perwakilan yang mereka pilih, akan tetapi wewenang untuk memerintah masyarakat harus berdasarkan persetujuan masyarakat itu sendiri. Hal ini menimbulkan konsekuensi bahwa segala keputusan publik harus melibatkan seluruh elemen masyarakat yang terkena dampak dari keputusan tersebut.

\section{Tinjauan Umum Sistem Pengisian Keanggotaan \\ a. Sistem pemilihan organis}

Pola pengisian keanggotaan lembaga perwakilan melalui pengangkatan atau

6. Voich dalam Kaelan, Pendidikan Pancasila, Op.cit, hlm.58.

7.Magnis Suseno dalam Hendra Nurtjahyo, 2006, Filsafat Demokrasi, Jakarta, Bumi Aksara, hlm. 34.

8.Arend Lijphart dalam Amir Makmur dan Reni Dwi Purnomowati, 2005, Lembaga Perwakilan Rakyat, Jakarta, FH UI, hlm.9. 
penunjukkan. Rakyat dianggap sebagai individu yang tergabung dalam organisasi. Organisasi tersebut sebagai pengendali hak politik dengan menunjuk wakil untuk mengisi lembaga perwakilan sesuai dengan jumlah yang diminta.

b. Sistem pemilihan mekanis

Rakyat suatu negara dianggap sebagai individu. Masing-masing individu berdiri sendiri sehingga mempunyai hak memberi suara1 orang 1 suara. Sistem ini sering disebut juga pemilihan umum.

\section{Tinjauan Umum Dewan Perwakilan Daerah}

Dewan Perwakilan Daerah terdiri atas wakil-wakil daerah provinsi yang dipilih melalui pemilihan umum. Anggota DPD dari setiap provinsi ditetapkan sebanyak empat orang. Jumlah seluruh Anggota DPD tidak lebih dari $1 / 3$ jumlah anggota DPR. Mengenai keanggotaan DPD ini diatur dalam Pasal 22C UUD 1945 pasca amandemen dalam ayat (1) Anggota DPD dipilih dari setiap provinsi melalui pemilu dan pemilu untuk memilih anggota DPD dilakukan secara individu bukan atas nama partai; (2) Anggota DPD dari setiap provinsi jumlahnya sama dan jumlah seluruh anggota DPD tidak lebih dari sepertiga jumlah anggota DPR; (3) Susunan dan kedudukan DPD diatur dengan UU. Adapun proses pemberhentian anggota DPD diatur dalam Pasal 22D ayat (4) UUD 1945 yang menyatakan "anggota DPD dapat diberhentikan dari jabatannya, yang syaratsyarat dan tata caranya diatur dalam undangundang. Berdasarkan Pasal 22D ayat (1), (2) dan (3)Undang-Undang Dasar Negara Republik Indonesia Tahun 1945, fungsi DPD meliputi fungsi legislasi, fungsi pertimbangan dan fungsi pengawasan.

\section{B. Hasil dan Pembahasan}

1. Sistem Pengisian Keanggotaan Dewan Perwakilan Daerah Republik Indonesia berdasarkan UndangUndang Nomor 8 Tahun 2012

Sistem distrik berwakil banyak dipakai dalam pemilihan umum anggota DPD sejak tahun 2004. Sistem distrik berwakil banyak artinya satu distrik pemilihan atau provinsi akan memilih wakil lebih dari satu orang, yaitu empat wakil. Mereka yang meraih suara terbanyak yang berhak menjadi anggota DPD RI. Apabila ada beberapa calon memproleh suara yang sama maka calon dengan penyebaran perolehan suara yang lebih merata menjadi pemenang atau ditetapkan sebagai calon terpilih.

Pasal 22E Undang-Undang Dasar Negara Republik Indonesia Tahun 1945 tercantum bahwa Pemilu untuk memilih anggota Dewan Perwakilan Rakyat, Dewan Perwakilan Daerah, dan Dewan Perwakilan Rakyat Daerah diselenggarakan berlandaskan asas langsung, umum, bebas, rahasia, jujur, dan adil setiap lima tahun sekali. Pemilu diselenggarakan dengan menjamin prinsip keterwakilan, yang artinya setiap orang Warga Negara Indonesia dijamin memiliki wakil yang duduk di lembaga perwakilan yang akan menyuarakan aspirasi rakyat di setiap tingkatan pemerintahan, dari pusat hingga ke daerah.

Tindak lanjut dari Undang-Undang Dasar Negara Indonesia Tahun 1945 mengenai Pemilu maka dibentuk UndangUndang tentang Pemilihan Umum Anggota DPR, DPD, dan DPRD. Adapun Tahapan Pemilu berdasarkan Pasal 4 ayat (2) UndangUndang Nomor 8 Tahun 2012 tentang Pemilu Anggota DPR, DPD, dan DPRD.

Tahapan Pemilu tersebut apabila dikaitkan dengan keanggotaan DPD maka diawali dengan peserta dan syarat Pemilu untuk memilih anggota DPD. Peserta Pemilu untuk memilih anggota DPD adalah perseorangan (Pasal 11 UU No. 8 Tahun 2012). Perseorangan sebagaimana dimaksud dalam Pasal 11 dapat menjadi Peserta Pemilu setelah memenuhi beberapa persyaratan :

a. warga Negara Indonesia yang telah berumur 21 (dua puluh satu) tahun atau lebih;

b. bertakwa kepada Tuhan Yang Maha Esa;

c. bertempat tinggal di wilayah Negara Kesatuan Republik Indonesia;

d. cakap berbicara, membaca, dan menulis dalam bahasa Indonesia;

e. berpendidikan paling rendah tamat 
sekolah menengah atas, madrasah aliyah, sekolah menengah kejuruan, madrasah aliyah kejuruan, atau pendidikan lain yang sederajat;

f. setia kepada Pancasila sebagai dasar negara, Undang-Undang Dasar Negara Republik Indonesia Tahun 1945, dan citacita Proklamasi 17 Agustus 1945;

g. tidak pernah dijatuhi pidana penjara berdasarkan putusan pengadilan yang telah mempunyai kekuatan hukum tetap karena melakukan tindak pidana yang diancam dengan pidana penjara 5 (lima) tahun atau lebih;

h. sehat jasmani dan rohani;

i. terdaftar sebagai Pemilih;

j. bersedia bekerja penuh waktu;

k. mengundurkan diri sebagai kepala daerah, wakil kepala daerah, pegawai negeri sipil, anggota Tentara Nasional Indonesia, anggota Kepolisian Negara Republik Indonesia, direksi, komisaris, dewan pengawas dan karyawan pada badan usaha milik negara dan/atau badan usaha milik daerah, atau badan lain yang anggarannya bersumber dari keuangan negara, yang dinyatakan dengan surat pengunduran diri yang tidak dapat ditarik kembali;

1. bersedia untuk tidak berpraktik sebagai akuntan publik, advokat/pengacara, notaris, pejabat pembuat akta tanah (PPAT), dan/atau tidak melakukan pekerjaan penyedia barang dan jasa yang berhubungan dengan keuangan negara serta pekerjaan lain yang dapat menimbulkan konflik kepentingan dengan tugas, wewenang, dan hak sebagai anggota DPD sesuai dengan ketentuan peraturan perundang-undangan;

$\mathrm{m}$. bersedia untuk tidak merangkap jabatan sebagai pejabat negara lainnya, direksi, komisaris, dewan pengawas dan karyawan pada badan usaha milik negara dan/atau badan usaha milik daerah serta badan lain yang anggarannya bersumber dari keuangan negara;

n. mencalonkan hanya di 1 (satu) lembaga perwakilan;

o. mencalonkan hanya di 1 (satu) daerah pemilihan; dan

p. mendapat dukungan minimal dari Pemilih di daerah pemilihan yang bersangkutan. Dukungan minimal dari daerah pemilihan diatur dalam Pasal 13 ayat (1) UU No. 8 Tahun 2012:

a. provinsi yang berpenduduk sampai dengan 1.000. 000 (satu juta) orang harus mendapatkan dukungan dari paling sedikit 1.000 (seribu) Pemilih;

b. provinsi yang berpenduduk lebih dari 1 . 000.000 (satu juta) sampai dengan 5. 000. 000 (lima juta) orang harus mendapatkan dukungan dari paling sedikit 2. 000 (dua ribu) Pemilih;

c. provinsi yang berpenduduk lebih dari 5 . 000. 000 (lima juta) sampai dengan 10 . 000. 000 (sepuluh juta) orang harus mendapatkan dukungan dari paling sedikit 3. 000 (tiga ribu) Pemilih;

d. provinsi yang berpenduduk lebih dari 10 . 000. 000 (sepuluh juta) sampai dengan 15 . 000. 000 (lima belas juta) orang harus mendapatkan dukungan dari paling sedikit 4. 000 (empat ribu) Pemilih; dan

e. provinsi yang berpenduduk lebih dari 15 . 000. 000 (lima belas juta) orang harus mendapatkan dukungan dari paling sedikit 5. 000 (lima ribu) Pemilih.

Dukungan sebagaimana dimaksud pada ayat (1) tersebar di paling sedikit 50\% (lima puluh persen) dari jumlah kabupaten/kota di provinsi yang bersangkutan. Seorang pendukung tidak dibolehkan memberikan dukungan kepada lebih dari satu orang calon anggota DPD serta melakukan perbuatan curang untuk menyesatkan seseorang, dengan memaksa, dengan menjanjikan atau dengan memberikan uang atau materi lainnya untuk memperoleh dukungan bagi pencalonan anggota DPD dalam Pemilu. Apabila ditemukan bukti adanya data palsu atau data yang sengaja digandakan oleh bakal calon anggota DPD terkait dengan dokumen persyaratan dukungan minimal pemilih, bakal calon anggota DPD dikenai pengurangan jumlah dukungan minimal Pemilih sebanyak 50 (lima puluh) kali temuan bukti data palsu atau data yang digandakan. Hal tersebut berdasarkan Pasal 70 ayat (3)UU No. 8 Tahun 2012.

Tahapan selanjutnya adalah penetapan 
jumlah kursi dan daerah pemilihan. Jumlah kursi anggota DPD untuk setiap provinsi ditetapkan 4 (empat), tercantum dalam Pasal 30 UU No. 8 Tahun 2012. Adapun Daerah pemilihan untuk anggota DPD adalah provinsi (Pasal 31 UU No. 8 Tahun 2012).

Adapun tahapan selanjutnya mengenai pencalonan anggota DPD. Tata cara pendaftaran calon anggota DPD melalui KPU Provinsi. Kelengkapan administratif yang harus diserahkan kepada KPU Provinsi diatur dalam Pasal 68 ayat (2) UU No. 8 Tahun 2012:

a. kartu tanda penduduk Warga Negara Indonesia;

b. bukti kelulusan berupa fotokopi ijazah, surat tanda tamat belajar (STTB), syahadah, sertifikat, atau surat keterangan lain yang dilegalisasi oleh satuan pendidikan atau program pendidikan menengah;

c. surat pernyataan di atas meterai bagi calon anggota DPD yang tidak pernah dipidana dengan ancaman hukuman 5 (lima) tahun atau lebih atau surat keterangan dari lembaga pemasyarakatan bagi calon yang pernah dijatuhi pidana;

d. surat keterangan sehat jasmani dan rohani;

e. surat tanda bukti telah terdaftar sebagai pemilih;

f. surat pernyataan tentang kesediaan untuk bekerja penuh waktu yang ditandatangani di atas kertas bermeterai cukup;

g. surat pernyataan kesediaan untuk tidak berpraktik sebagai akuntan publik, advokat/pengacara, notaris, pejabat pembuat akta tanah (PPAT), dan pekerjaan penyedia barang dan jasa yang berhubungan dengan keuangan negara serta pekerjaan lain yang dapat menimbulkan konflik kepentingan dengan tugas, wewenang, dan hak sebagai anggota DPD yang ditandatangani di atas kertas bermeterai cukup;

h. surat pengunduran diri yang tidak dapat ditarik kembali sebagai kepala daerah, pegawai negeri sipil, anggota Tentara Nasional Indonesia, atau anggota Kepolisian Negara Republik Indonesia, direksi, komisaris, dewan pengawas dan karyawan pada badan usaha milik negara dan/atau badan usaha milik daerah, pengurus pada badan lain yang anggarannya bersumber dari anggaran pendapatan dan belanja negara dan/atau anggaran pendapatan dan belanja daerah; dan

i. surat pernyataan tentang kesediaan hanya mencalonkan untuk 1 (satu) lembaga perwakilan yang ditandatangani di atas kertas bermeterai cukup

Verifikasi kelengkapan dan kebenaran dokumen persyaratan bakal calon anggota DPD dilakukan oleh Komisi Pemilihan Umum (selanjutnya disebut KPU), yang dibantu pelaksanaannya oleh KPU Provinsi dan KPU Kabupaten/Kota. Adapun Badan Pengawas Pemilu (selanjutnya disebut Bawaslu), Bawaslu Provinsi, dan Panitia Pengawas Pemilu (selanjutnya disebut Panwaslu) Kabupaten/Kota melakukan pengawasan atas pelaksanaan verifikasi kelengkapan persyaratan administrasi bakal calon anggota DPD yang dilakukan oleh KPU, KPU Provinsi, dan KPU Kabupaten/Kota.

KPU mengumumkan di media massa cetak harian dan media massa elektronik nasional dan 1 (satu) media massa cetak harian dan media massa elektronik daerah serta sarana pengumuman lainnya mengenai penetapan daftar calon sementara, untuk mendapatkan masukan dan tanggapan masyarakat, sebagaimana dimaksud dalam Pasal 72 ayat (3), disampaikan secara tertulis kepada KPU dengan disertai bukti identitas diri. Apabila ditemukan dugaan telah terjadi pemalsuan dokumen atau penggunaan dokumen palsu dalam persyaratan administrasi bakal calon dan/atau calon anggota DPD, maka KPU dan KPU Provinsi berkoordinasi dengan Kepolisian Negara $\mathrm{R}$ e p u b lik I n d o e s i a u t u k menindaklanjutinya sesuai dengan ketentuan peraturan perundang-undangan. Akan tetapi dalam hal putusan pengadilan yang mempunyai kekuatan hukum tetap yang menyatakan tidak terbukti adanya pemalsuan dokumen atau penggunaan dokumen palsu sebagaimana dimaksud dalam Pasal 74 
dibacakan setelah KPU dan KPU Provinsi menetapkan daftar calon tetap anggota DPD, putusan tersebut tidak memengaruhi daftar calon tetap, tercantum dalam Pasal 75 UU No. 8 Tahun 2012 . Selanjutnya KPU mengumumkan daftar calon tetap disusun berdasarkan abjad dan dilengkapi dengan pas foto diri terbaru.

Pada tahapan masa kampanye Pemilu, berkaitan dengan pencalonan anggota DPD, diatur dalam Pasal 79 UU No. 8 Tahun 2012. Pelaksana Kampanye Pemilu anggota DPD terdiri atas calon anggota DPD, orang seorang, dan organisasi yang ditunjuk oleh Peserta Pemilu anggota DPD. Materi kampanye Perseorangan Peserta Pemilu yang dilaksanakan oleh calon anggota DPD meliputi visi, misi, dan program yang bersangkutan. Masa Kampanye Pemilu dilaksanakan sejak 3 (tiga) hari setelah calon Peserta Pemilu ditetapkan sebagai Peserta Pemilu sampai dengan dimulainya Masa Tenang, kecuali untuk metode kampanye berupa iklan media massa cetak dan media massa elektronik serta rapat umum dilaksanakan selama 21 (dua puluh satu) hari dan berakhir sampai dengan dimulainya Masa Tenang. Masa Tenang berlangsung selama 3 (tiga) hari sebelum hari pemungutan suara.

Selain itu berdasarkan Pasal 134 ayat (2) UU No. 8 Tahun 2012 bahwa Calon anggota DPD Peserta Pemilu wajib memberikan laporan awal dana Kampanye Pemilu dan rekening khusus dana Kampanye Pemilu kepada KPU melalui KPU Provinsi paling lambat 14 (empat belas) hari sebelum hari pertama jadwal pelaksanaan Kampanye Pemilu dalam bentuk rapat umum. Apabila calon anggota DPD Peserta Pemilu tidak menyampaikan laporan awal dana Kampanye Pemilu kepada KPU melalui KPU Provinsi sampai batas waktu, maka berdasarkan Pasal 138 ayat (2) UU No. 8 Tahun 2012, calon anggota DPD yang bersangkutan dikenai sanksi berupa pembatalan sebagai Peserta Pemilu. Calon anggota DPD juga dikenai sanksi tidak ditetapkan menjadi calon terpilih apabila calon anggota DPD Peserta Pemilu tidak menyampaikan laporan penerimaan dan pengeluaran danaKampanye Pemilu kepada kantor akuntan publik yang ditunjuk oleh
KPU sampai batas waktu.

Penghitungan suara dalam Pemilu dilakukan secara transparan dan dapat dipertanggungjawabkan, sebagaimana diatur dalam Bab XI UU No. 8 Tahun 2012. Adapun Pasal 207 ayat (1) UU No. 8 Tahun 2012 tercantum bahwa KPU menetapkan hasil Pemilu secara nasional paling lambat 30 (tiga puluh) hari setelah hari pemungutan suara.

Tahapan yang terakhir adalah penetapan hasil Pemilu. Penetapan calon terpilih anggota DPD berdasarkan Pasal 216 Ayat (1) UU No. 8 Tahun 2012, yaitu calon yang memperoleh suara terbanyak pertama, kedua, ketiga, dan keempat di provinsi yang bersangkutan. Akan tetapi dalam ayat (2) disebutkan apabila calon terpilih keempat terdapat jumlah suara yang sama, calon yang memperoleh dukungan Pemilih yang lebih merata penyebarannya di seluruh kabupaten/kota di provinsi tersebut ditetapkan sebagai calon terpilih.

\section{Implikasi Sistem Pengisian Keanggotaan Dewan Perwakilan Daerah Republik Indonesia terhadap Nilai-Nilai Pancasila}

Pengisian keangotaan tersebut apabila dikaitkan dengan nilai-nilai Pancasila maka menimbulkan implikasi. Adapun implikasi sistem pengisian keanggotaan DPD terhadap nilai-nilai Pancasila berkaitan dengan Pancasila sebagai tertib hukum Indonesia, Pancasila sebagai sumber hukum materiil, dan penjabaran nilai-nilai Pancasila dalam Asas-Asas Hukum (Asas-asas Hukum yang dapat ditarik dari Pancasila).

Dilihat dari kedudukan Pancasila dalam Pembukaan Undang-Undang Dasar 1945 serta memperhatikan pula perumusan fungsi dalam pembukaan tersebut, maka Pancasila merupakan Grundnorm tidak hanya dari norma-norma hukum, tetapi dari seluruh norma-norma kehidupan bangsa Indonesia. Dengan demikian, maka dapat diutarakan Pancasila dan tertib hukum Indonesia sebagai berikut: ${ }^{9}$

a. Pancasila adalah suatu Grundnorm (norma dasar), bagi kehidupan bangsa, masyarakat dan negara Indonesia.

9. Roeslan Saleh,1979, Penjabaran Pancasila dan UUD 45 dalam Perundang-Undangan, Jakarta, Aksara Baru, hlm.38. 
Pancasila lebih luas daripada apa yang dikemukakan oleh Hans Kelsen yang membahas Grundnorm hanya sebagai norma dasar dari suatu tertib hukum. Oleh karena itu, jika lazimnya orang mengemukakan ketunggal-ikaan juridis dalam ke-bhineka-an norma-norma hukum, dengan Pancasila kita dapat mengkonstruksikan ketunggal-ikaan dalam ke-bhinneka-an norma-norma.

b. Pancasila bukan hanya norma dasar dari kehidupan hukum dan tertib hukum Indonesia, tetapi adalah juga norma dasar dari norma-norma lain seperti norma moral, kesusilaan, etik dan sebagainya.

c. Pancasila mengharuskan tertib hukum Indonesia juga serasi dengan normanorma moral, kesusilaan, etik dan sebagainya, karena di dalam Pancasila terkandung pula norma-norma tersebut.

Pancasila adalah sumber hukum materiil dari hukum Indonesia, sehingga pikiran-pikiran hukum dan rancangan undang-undang yang tidak sesuai dengan Pancasila tidak boleh ditetapkan. Di sinilah Pancasila berkedudukan sebagai dasar dari tertib hukum Indonesia, sebagai pedoman dan penunjuk arah dari perkembangannya. ${ }^{10}$

Pancasila sebagai tertib hukum Indonesia makasifat Pancasila sebagai Grundnorm yang metajuristic, artinya berada di luar sistem hukum dan menjadi landasan tertinggi tatanan hukum positif. Pancasila tertuang dalam Pembukaan Undang-Undang Dasar Negara RI Tahun 1945. Keterkaitan Pancasila dan Pembukaan Undang-Undang Dasar 1945 bukan hanya karena Pancasila dapat dibaca pada alinea ke-4 Pembukaan, melainkan harus ditelusuri pula melalui pokok-pokok pikiran Pembukaan UndangUndang Dasar 1945. Rumusan empat pokok pikiran tersebut tercantum dalam dokumen Penjelasan Undang-Undang Dasar $1945^{11}$ apabila dikaitkan dengan sistem pemilu distrik berwakil banyak, maka

a. Pengertian negara persatuan (mengandung muatan sila ke-3 Pancasila), negara yang melindungi dan meliputi segenap bangsa seluruhnya, sehingga mengatasi segala paham golongan dan paham perseorangan. Dalam sistem pemilu distrik berwakil banyak, adanya suara yang hilang, dikarenakan hanya memiliki 4 (empat) orang yang terpilih menjadi anggota Dewan Perwakilan Daerah. Selain itu sistem ini kurang mengakomodasi kepentingan masyarakat yang heterogen.

b. Negara hendak mewujudkan keadilan sosial bagi seluruh rakyat (mengandung muatan sila ke-5). Dalam sistem distrik, negara dibagi dalam sejumlah besar distrikpemilihan (kecil) yang kira-kira sama jumlah penduduknya. Akan tetapi di Indonesia sistem distrik ini tanpa membedakan jumlah penduduk dan besarnya wilayah masing-masing provinsi.

c. Negara yang berkedaulatan Rakyat, berdasar atas kerakyatan dan permusyawaratan perwakilan (Sila ke-4). Sistem negara yang terbentuk dalam undang-Undang Dasar harus berdasar atas kedaulatan Rayat dan berdasar atas permusyawaratan perwakilan. Tidak terakomodirnya suara minoritas dalam sistem distrik berwakil banyak maka makna permusyawaratan perwakilan menjadi hilang.

d. Negara berdasar atas Ketuhanan Yang Maha Esa menurut dasar kemanusiaan yang adil dan beradab. Undang-Undang Dasar harus mengandung isi yang mewajibkan pemerintah dan lain-lain penyelenggara negara untuk memelihara budi pekerti kemanusiaan yang luhur dan memegang teguh cita-cita moral rakyat yang luhur. (sila ke-1 dan ke-2). Kelemahan-kelemahan dalam sistem distrik berwakil banyak, menyebabkan kepentingan daerah lebih diutamakan, kurang mengakomodir kepentingan masyarakat, suara minoritas menjadi hilang, bagaimana mungkin sila kedua terlebih lagi sila pertama dapat diterapkan.

Pancasila sebagai sumber hukum materiil

10. Ibid., hlm.44-45.

11. Sekretariat Negara Republik Indonesia, 2009, Kumpulan Undang-Undang Dasar Negara Republik Indoenesia, Jakarta, Setneg, 
maka nilai-nilai Pancasila yang terkandung di dalamnya harus dijadikan sumber inspirasi dan sumber rujukan dalam penciptaan hukum, pembentukan hukum, dan pembaruan hukum. Pancasila itu lahir dan digali dari nilai-nilai adat-istiadat, nilai-nilai kebudayaan, serta nilai-nilai kerohanian yang telah tumbuh dan hidup sejak dahulu kala. Yang kemudian dijadikan sebagai suatu falsafah bangsa, staatsidee (cita bangsa), maupun rechtsidee (cita hukum) bagi bangsa Indonesia.

Nilai-nilai dasar Pancasila dan karakter cita hukum dalam pembentukan hukum masih sangat abstrak, sehingga kemudian dijabarkan dalam asas-asas hukum. Asas hukumbukan merupakan hukum konkret, melainkan merupakan pikiran dasar yang umum dan abstrak, atau merupakan latar belakang peraturan konkret yang terdapat dalam dan di belakang setiap sistem hukum yang terjelma dalam peraturan perundangundangan dan putusan hakim yang merupakan hukum positif dan dapat diketemukan dengan mencari sifat-sifat atau ciri-ciri yang umum dalam peraturan konkret tersebut. $^{12}$

Implikasi sistem pengisian keanggotaan Dewan Perwakilan Daerah terhadap nilai-nilai Pancasila berkaitan dengan asas-asas hukum, maka asas hukum yang dapat ditarik dari Pancasila adalah sebagai berikut:

Asas kesatuan dan persatuan atau kebangsaan mengamanatkan bahwa hukum Indonesia harus merupakan hukum nasional yang berlaku bagi seluruh bangsa Indonesia. Hukum nasional berfungsi mempersatukan bangsa Indonesia. Asas ke-Tuhanan mengamanatkan bahwa tidak boleh ada produk hukum nasional yang bertentangan dengan agama atau bersifat menolak atau bermusuhan dengan agama. Asas demokrasi mengamanatkan bahwa dalam hubungan antara hukum dan kekuasaan, kekuasaan harus tunduk pada hukum, bukan sebaliknya. Pada analisis terakhir kekuasaan ada pada rakyat dan wakil-wakilnya. Asas keadilan sosial mengamanatkan bahwa semua warga negara mempunyai hak yang sama dan bahwa semua orang sama dihadapan hukum.

Pengisian keanggotaan DPD dengan sistem distrik berwakil banyak, dengan segala kelemahannya, telah menyimpangi asas hukum yang dapat ditarik dengan Pancasila tersebut. Wakil yang terpilih cenderung memperhatikan kepentingan daerah daripada kepentingan nasional jelas dapat membahayakan nilai Pancasila, dalam hal ini asas kesatuan dan persatuan atau kebangsaan. Adanya over representation dari partai besar dalam lembaga perwakilan sehingga kurang mengakomodasi kepentingan dalam masyarakat yang heterogen maka asas demokrasi menjadi terabaikan.

Demokrasi di Indonesia, yakni sistem pengambilan keputusan di dalam penyelenggaraan demokrasi, ditekankan pada konsep permusyawaratan dan konsep mufakat yang bersumber dari tatanan asli Indonesia. Konsep permusyawaratan mufakat dan perwakilan, yang kemudian tertuang dalam sila ke empat Pancasila, merupakan bukti bahwa Indonesia negara yang berkedaulatan rakyat, berdasar kerakyatan dan permusyawaratan perwakilan. Sebuah demokrasi, yang menitikberatkan seluruh rakyat dan kepentingannya, menjadi poros penyelenggaraan negara. Bukan mayoritasminoritas, tetapi keseluruhan rakyat.

Demokrasi yang ditetapkan dalam pokok pikiran Pembukaan Undang-Undang Dasar 1945, baik sebelum maupun sesudah perubahan, adalah melalui hikmah $\mathrm{k} \mathrm{e} \mathrm{bijaks} \mathrm{a} \mathrm{n} \mathrm{a} \mathrm{n}$ a $1 \mathrm{a} m$ permusyawaratan/perwakilan, bukan demokrasi langsung dengan cara pengambilan suara one person one vote, sebagaimana sekarang ditetapkan dalam perubahan Undang-Undang Dasar 1945, sehingga meninggalkan asas musyawarah mufakat dalam permusyawaratan / perwakilan.

12. Setelah menguraikan dan membandingkan pendapat dari Bellefroid, van Eikema Hommes, van der Velde, dan Scholten, dalam Sudikno Mertokusumo, Penemuan Hukum Sebuah Pengantar, dalam Fadjar, Mukthie, dkk., 2010, Konstitusionalisme Demokrasi (Sebuah Diskursus tentang Pemilu, Otonomi Daerah dan Mahkamah Konstitusi sebagai Kado untuk 'Sang Penggembala' Prof. A.Mukthie Fadjar, S.H., MS.), Malang, In-TRANS Publishing, hlm. 201. 


\section{Simpulan dan Saran}

Berdasarkan hasil penelitian dan pembahasan dapat ditarik kesimpulan sebagai berikut :

1. Pengisian keanggotaan DPD berdasarkan Pasal 5 ayat (2) UndangUndang Nomor 8 Tahun 2012, melalui Pemilihan Umum dengan sistem distrik berwakil banyak. Sistem distrik berwakil banyak artinya bahwa dalam 1 (satu) provinsi memilih 4 (empat) wakil. Sistem ini di terapkan di Indonesia tanpa membedayakan jumlah penduduk dan luas wilayah. Undangundang ini juga mengatur mengenai syarat bakal calon anggota DPD dan sanksi dalam pemalsuan syarat; dukungan minimal dari daerah pemilihan bagi bakal calon anggota DPD dan akibat apabila melakukan tindakan curang; verifikas i kelengkapan dan kebenaran oleh Komisi Pemilihan Umum; masukan dan tanggapan dari masyarakat untuk perbaikan daftar calon sementara; laporan awal dana kampanye bagi calon anggota DPD; dan sanksi pembatalan sebagai peserta pemilihan umum anggota DPD.

2. Implikasi sistem pengisian keanggotaan DPD terhadap nilai-nilai Pancasila berkaitan dengan Pancasila sebagai tertib hukum Indonesia, Pancasila sebagai sumber hukum materiil, dan penjabaran nilai-nilai Pancasila dalam Asas-Asas Hukum (Asas-asas Hukum yang dapat ditarik dari Pancasila).

Adapun saran berdasarkan hasil penelitian ini yaitu perlunya suatu sistem pengisian keanggotaan DPD yang didasarkan pada nilai-nilai Pancasila. Bukan demokrasi langsung dengan cara pengambilan suara one person one vote, sehingga meninggalkan asas m us yawarah m ufakat dala m permusyawaratan/perwakilan.

\section{DAFTAR PUSTAKA}

Budiarjo, Miriam, 2008, Dasar-Dasar Ilmu Politik (Edisi Revisi), Jakarta : Gramedia Pustaka Utama

Hamidi, Jazim, 2006, Revolusi Hukum Indonesia (Makna, Kedudukan, dan Implikasi Hukum Naskah Proklamasi 17 Agustus 1945 dalam Sistem Ketatanegaraan RI), Jakarta: Konstitusi Press.

Kaelan, 2010, Pendidikan Pancasila, Yogyakarta: Paradigma.

Kelompok DPD di MPR RI, 2007, Untuk Apa DPD RI, Jakarta: Kelompok DPD di MPR RI.

Latif, Yudi, 2011, Negara Paripurna: Historitas, Rasionalitas, dan Aktualitas Pancasila, Jakarta: PT Gramedia.

Makmur, Amir dan Reni Dwi Purnomowati, 2005, Lembaga Perwakilan Rakyat, Jakarta:FHUI.

Mukthie, Fadjar, dkk., 2010 , Konstitusionalisme Demokrasi (Sebuah Diskursus tentang Pemilu, Otonomi Daerah dan Mahkamah Konstitusi sebagai Kado untuk 'Sang Penggembala' Prof. A. Mukthie Fadjar, S. H. , MS. ), Malang: In-TRANS Publishing.

Nurtjahyo, Hendra, 2006 , Filsafat Demokrasi, Jakarta: Bumi Aksara.

Purnama, Eddy, 2007, Negara Kedaulatan Rakyat, Bandung: Nusamedia.

Saleh, Roeslan, 1979, Penjabaran Pancasila dan UUD 45 dalam PerundangUndangan, Jakarta, Aksara Baru.

Sekretariat Jendral MPR RI, 2006, Panduan Pemasyarakatan Undang-Undang Dasar Negara Republik Indonesia, Tahun1945, Jakarta: Setjen MPR RI.

Sekretariat Negara Republik Indonesia, 2009, Kumpulan Undang-Undang Dasar Negara Republik Indoenesia, Jakarta: Setneg. 
MMH, Jilid 44 No. 4, Oktober 2015

Shidarta, "Menilik Kepantasan Labelisasi $\mathrm{P}$ a n c a s i l a s e b a g a i Staatsfundamentalnorm dalam Sistem Hukum Indonesia", sebuah Makalah yang dipresentasikan pada Seminar Nasional "Membangkitkan Semangat Konstitusi Berdasarkan Nilai-Nilai Pancasila dalam Negara Hukum Indonesia" oleh BEM Fakultas Hukum UNDIP, (Semarang, 1 Desember 2012).

Soekanto, Soerjono dan Sri Mamudji, 2001, Penelitian Hukum Normatif Suatu Tinjauan Singkat, Jakarta: PT Raja Grafindo Persada.

Wahyudi, Alwi, 2012, Hukum Tata Negara Indonesia dalam Perspektif Pancasila Pasca Reformasi, Yogyakarta: Pustaka Pelajar, 2012.

Undang-Undang Dasar Negara Republik Indonesia Tahun 1945

Undang-Undang Nomor 8 Tahun 2012 tentang Pemilihan Umum Anggota DPR, DPD, dan DPRD.

Undang-Undang Nomor 12 Tahun 2011 tentang Pembentukan Peraturan Perundang-Undangan. 